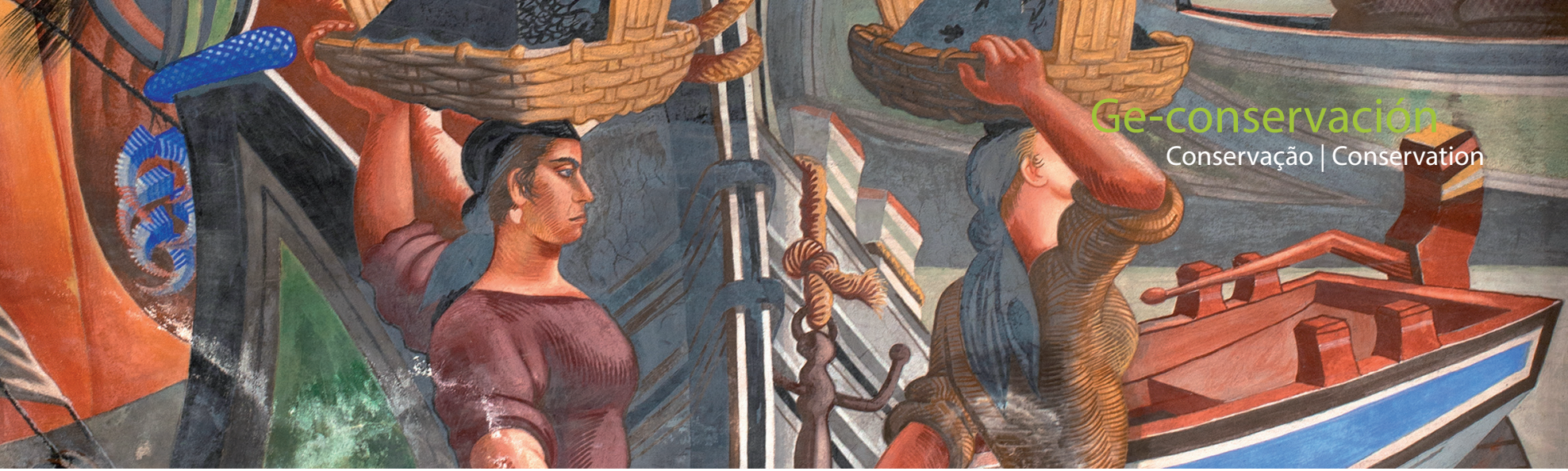

\title{
Unveiling the mural painting art of Almada Negreiros at the Maritime Stations of Alcântara (Lisbon): diagnosis research of paint layers as a guide for its future conservation
}

\author{
Milene Gil, Mafalda Costa, Mila Cretkovic, Carlo Bottaini, Ana Cardoso, Ana Manhita, Cristina \\ Dias, António Candeias
}

\begin{abstract}
This paper reports the diagnostic research of deteriorated paint layers from three mural panels made by Almada Negreiros found in the Alcântara Maritime Station in Lisbon. The aim was to understand the main decay phenomena to aid future conservation works. The methodology comprised in-situ analyses by technical photography in Vis, Vis-RaK and UVF, p-OM and h-EDXRF; micro sampling; OM, SEM-EDS, $\mu$-XRD, $\mu$-Raman, $\mu$-FT-IR and Py-GC/MS. Preliminary results show that all the paint layers analyzed are affected by salts (alkali sulphates) that over time have caused flacking, lack of cohesion, erosion, and lacunae. The light greenish/greenish bluish paint layers in all three panels are the most affected. No organic binders were identified, only the presence of vinyl polymer in glossy paint surfaces.
\end{abstract}

Keywords: Almada Negreiros, mural paintings, diagnostic research, SEM-EDS, $\mu$-XRD, $\mu$-FT-IR, Py-GC/MS

Presentación del arte de la pintura mural de Almada Negreiros en las Estaciones Marítimas de Alcântara (Lisboa): investigación diagnóstica de capas de pintura como guía para su futura conservación

Resumen: Este artículo informa de la investigación de diagnóstico de capas de pintura deterioradas de tres paneles murales realizados por Almada Negreiros en la estación marítima de Alcântara en Lisboa. El objetivo era comprender los principales fenómenos de descomposición para ayudar a futuros trabajos de conservación. La metodología comprendió análisis in situ mediante fotografía técnica en Vis, Vis-RaK y UVF, p-OM y h-EDXRF; micro muestreo; OM, SEM- EDS, $\mu$-XRD, $\mu$-Raman, $\mu$-FT-IR y Py-GC/MS. Los primos resultados muestran que todas las capas de pintura analizadas están afectadas por sales (sulfatos) que a lo largo del tiempo han provocado escamas, falta de cohesión, erosión y lagunas. Las capas de pintura de color verde claro/verde claro azulado en los tres paneles son las más logradas. No se encontraron aglutinantes orgánicos, solo la presencia de polímero de vinilo en superficies de pintura brillante.

Palabras clave: Almada Negreiros, pinturas murales, diagnóstico, SEM-EDS, $\mu-X R D, \mu-F T-I R$, Py-GC/MS

\section{Desvendar a arte da pintura mural de Almada Negreiros nas estações marítimas de Alcântara (Lisboa): Diagnóstico de camadas cromáticas como guia para sua conservação futura}

Resumo: Este artigo relata uma pesquisa de diagnóstico de camadas cromáticas deterioradas em três pinturas murais pintadas por Almada na Estação Marítima de Alcântara, em Lisboa. O objetivo foi o entendimento dos principais fenómenos de deterioração como apoio a futuros trabalhos de conservação. A configuração analítica foi composta por afotografia técnica no Vis, Vis-Ras e UVF, p-OM e h-EDXRF; micro-amostragem; OM, SEM-EDS, $\mu$-XRD, $\mu$-Raman, FT-IR e Py-GC/MS. Os primeiros resultados mostram que todas as camadas cromáticas analisadas estão afectadas por sais (sulfatos) que ao longo do tempo tem causado perdas de adesão e de coesão, erosão e lacunas. As camadas cromáticas verdes-claras/verde-claras azuladas presente em todos os painéis são as mais atingidas. Aglutinantes não foram identificados, mas somente a presença de polímeros vinílicos nas superfícies pintadas com brilho.

Palavras-chave: Almada Negreiros, pinturas murais, diagnóstico, SEM-EDS, $\mu-X R D, \mu-F T-I R, P y-G C / M S$ 


\section{Introduction}

Almada Negreiros was born on the $7^{\text {th }}$ of April 1893 in São Tomé e Principe, Africa. As a key artist from the Portuguese Modern art, he would be recognized as painter, as sculptor and as writer (França 2004, 2014). His versatile background made him one of the most famous artists of the 20th century. He died in Lisbon on the $15^{\text {th }}$ of June 1970 and left behind a rich opus (França 2004). In the period between 1943 and 1949, he decorated the walls of the two Maritime Stations in Lisbon with remarkable murals, eight of them in Alcântara and six in Rocha de Conde de Óbidos (Lobo 2014; Monteiro 2012). The two Maritime Stations stretch for 1.5 $\mathrm{km}$ along the Tejo riverside and represent the main port in Portugal, connecting the city of Lisbon with the Atlantic Ocean. These stations are in Alcântara, close to one of the most important traffic arteriae of Lisbon (highways N6 and E1), and to railway and subway stations (Alcântara and Cais do Sodré, respectively).

The diagnostic research undertaken focuses on a collection of three murals painted between 1943 and 1945 at the main hall of Alcântara Maritime Station. In total, eight mural panels with $7.20 \times 3.80$ meters are presented on the east and west walls: two triptychs and two individual paintings. This research is constrained to the mural panels, referred to as P2, P3 and P6, that depict scenes of everyday life and the mythological history of nau catrineta [Figure 1].

Three research questions were posed:

1. Which paint layers are more deteriorated and is this deterioration linked to a specific pigment?

2. Which are the main decay phenomena and what are their dynamics?
3. What is the role of the painting techniques when it comes to stability and deterioration of the pigments?

This paper reports the first results from the analytical campaign held in situ and in a laboratory context between May and September 2020. The survey was made on the framework of a wider project entitled Unveiling the mural art of Almada Negreiros (PTDC/ART-HIS/1370/2020) that aims to study the painting techniques and pigments used by the artist and its implications in the deterioration processes encountered by Conservators-Restorers in the past 30 years.

\section{Experimental}

Diagnostic survey included in situ non-invasive analysis which were complemented by laboratory micro-analytical analysis of micro-samples collected from deteriorated and stable paint layers, as well as salt efflorescence.

\section{— Photo Documentation and Technical Photography in situ (TP)}

Photographs were acquired in visible (Vis), visible raking (Vis-RAK) and ultraviolet light (UVF), and taken with a Nikon D3200 camera, with 24Mpx, and objective Nikkor 18-55mm f:3.5-5.6 Gll. They were obtained under the angle of $15-20^{\circ}$ from the painting surface, from three different sides. UV induced fluorescence in visible (UVF) photography was used to discover previous interventions or presence of organic binders. UVF photograph was taken with Nikon D3200 camera and Labino ${ }^{\circledR}$ MPXL UV
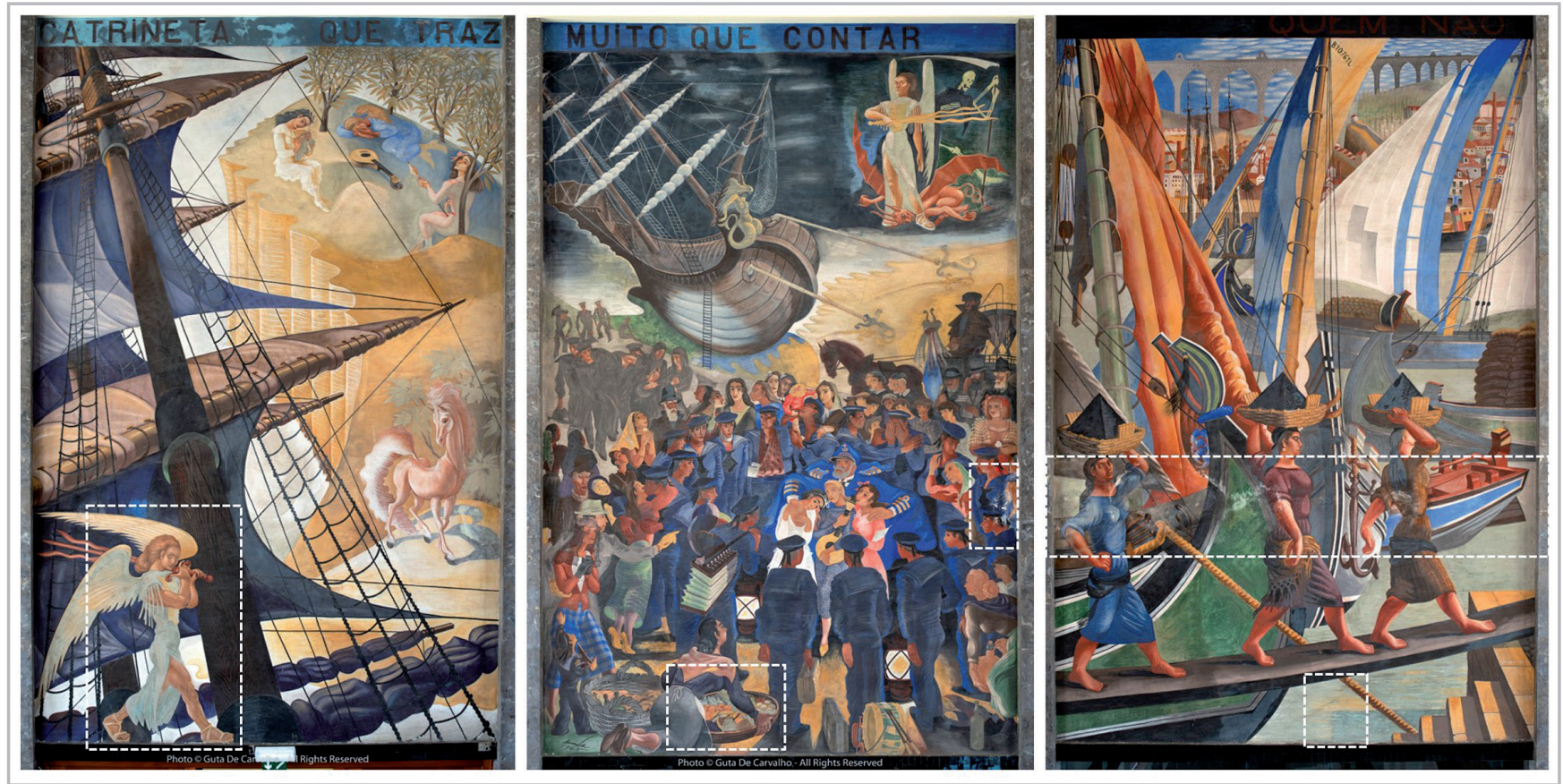

Figure 1.- Murals P2, P3 and P6 with the location of the deteriorated paint layers analyzed in 2020 (white squares) (photos by Guta Carvalho 2020 @ all rights reserved). 
PS135 light (35W PS135 UV Midlight 230V) with UV filter included (310-400mmand a peak at $365 \mathrm{~mm}$ ), a midlight distribution angle of $20^{\circ}$ and a start-up time full power after 5-15sec.

\section{- Portable optical microscopy (p-OM)}

Two portable microscopes Dinolite PRO AM13T-FVW and DinoLite Premier AD3713TB were used with 20 and $434 x$ magnifications to record details of the deterioration features and pigment particles.

\section{- Handled X-ray Fluorescence ( $h$-EDXRF)}

Handled X-ray fluorescence allowed a preliminary in situ and non-invasive identification of the elemental composition of the painting materials. A handheld X-ray fluorescence analyzer Bruker Tracer III SD was used, equipped with an X-ray tube with rhodium target and a silicon drift detector. A total of 83 paint areas covering the entire palette's color range were analyzed. Spectra were recorded using a voltage and a current intensity of $40 \mathrm{kV}$ and $30 \mu \mathrm{A}$, respectively, during a $30 \mathrm{~s}$ real-time count. The instrument was controlled using the S1PXRF software $\left(\right.$ Bruker $\left.^{\mathrm{TM}}\right)$. The spectra were later processed using the $\operatorname{Artax}\left(\right.$ Bruker $\left.^{\mathrm{TM}}\right)$ software to obtain semi-quantitative data.

\section{- Optical microscopy (OM)}

First step in laboratory analysis was optical microscopic documentation of micro fragments, collected from different paint layers. Cross sections were embedded in epoxy fix resin and studied using a Leica DM2500M reflected light optical microscope in dark field illumination mode. Observations were carried out under 100x, 200x and 500x magnification. Photographs of cross sections were obtained with a Leica MC $170 \mathrm{HD}$ digital camera Leica software. UV mode was used to spot the presence of organic materials. A Leica M205C stereomicroscope was also used to obtain images of both powder samples and cross sections in magnifications $7.8 \mathrm{x}-160 \mathrm{x}$. The stereomicroscope used is equipped with a Leica DFC295 digital camera and external illumination.

\section{- micro-X-ray Diffraction $(\mu-X R D)$}

A Bruker D8 Discover ${ }^{\circledast}$ diffractometer using Cu Ka radiation was employed to identify the main mineralogical phases in the salt efflorescence. The samples were mounted as powder on a zero-background specimen holder. An angular range of $3-75^{\circ} 2 \theta$, step size of $0.05 \% / s$ and step time of $2 \mathrm{~s}$ was used for collecting the diffractograms. Identification of crystalline phases was performed using the DIFFRAC.SUITE EVA ${ }^{\circledR}$ software and the ICDD PDF-2 database.

\section{- Scanning Electron Microscopy - Energy Dispersive Spectroscopy (SEM-EDS)}

Scanning electron microscope (SEM) coupled with an energy dispersive spectrometer (EDS) enabled the obtention of high resolution images and elemental analysis of the micro samples. Backscattering mode (BSE) was used to document micro-morphology of the paint layers and salt efflorescence. This analysis was carried out with a variable pressure SEM HITACHI S-3700N operator with an accelerating voltage of $20 \mathrm{kV}$ and at $40 \mathrm{~Pa}$. SEM was coupled with Bruker XFlash 5010 Silicon Drift Detector (SDD) with resolution of $129 \mathrm{eV}$ at Mn Ka.

\section{- micro - Fourier Transform Infrared Spectroscopy $(\mu-F T$-IR)}

For the detection of organic compounds, Fourier transformed infrared spectroscopy was carried out. Samples were collected from the panels by gently scratching the paint surface. Powder samples were analyzed using a Bruker Tensor 27 Mid-IR (MIR) spectrometer, coupled with HYPERION 3000 microscope, and controlled by OPUS 7.2 software with corresponding OPUS library (copyright $\odot 2012$ Bruker Optics and Microanalysis GmbH, Berlin, Germany). A MCT (Mercury Cadmium Telluride) detector was used, cooled with liquid nitrogen. Analyses were done in transmission mode using a $15 x$ objective and an EX'Press $1.6 \mathrm{~mm}$ diamond compression microcell, STJ-0169. Spectra were plotted in region of $4000-600 \mathrm{~cm}^{-1}$, with 64 scans and $4 \mathrm{~cm}^{-1}$ resolution.

\section{- micro - Raman Spectroscopy}

Powder samples of green pigment layers were analyzed using a HORIBA XPlora Raman spectrometer, equipped with a $785 \mathrm{~nm}$ red diode laser, and coupled with an Olympus $^{\mathrm{TM}}$ microscope. The system uses a thermoelectrically cooled charge-coupled device detector (CCD). The calibration of the instrument was performed with the Raman band of a silicon crystal at $520 \mathrm{~cm}^{-1}$. Raman spectra were acquired in the $100-2000 \mathrm{~cm}-1$ region. The measuring time, laser power, and number of accumulations were set to obtain a good signal-to-noise ratio while avoiding thermal damage. The $50 \times$ objective was used for all the samples. The instrument itself was controlled using the LabSpec software. The collected Raman spectra were further processed in GRAMS (ThermoFisher Scientific ${ }^{\mathrm{TM}}$ ).

\section{- Pyrolysis Gas Chromatography coupled with Mass Spectrometry (Py-GC/MS)}

For identification of organic components, pyrolysis-gas chromatography coupled with mass spectrometry was 

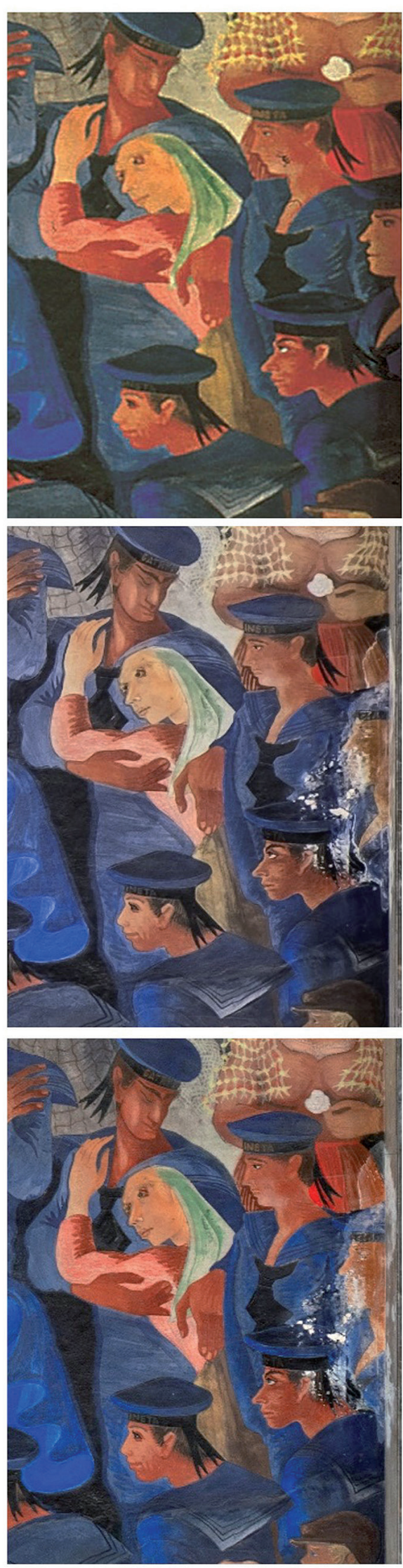

Figure 2.- Three images of a detail of P3. From top to bottom, APL Archival (late 1990s), CML-José Vicente (July 2013), Guta Carvalho (June 2020). Salt veils and efflorescence's are visible on the right border of the panel (photo credits $\odot$ all rights reserved). selected. A Frontier Lab PY-3030D double-shot pyrolyser coupled to a Shimadzu GC2010 gas chromatographer and a Shimadzu GCMS-QP2010 Plus mass spectrometer were used. Pyrolysis interface was maintained at a temperature of $280^{\circ} \mathrm{C}$. A capillary column Phenomenex Zebron-ZB-5HT was used for separation, with helium as carrier gas, adjusted to a flow rate of $1.5 \mathrm{ml} \mathrm{min}$ 1. The mass spectrometer was programmed to acquire data between 40 and $1090 \mathrm{~m} / \mathrm{z}$. The sample $(<200 \mu \mathrm{g})$ was previously derivatized with $3 \mu \mathrm{L}$ of tetramethylammonium hydroxide $(2.5 \%$ in methanol, v/v) in a 50- $\mu \mathrm{L}$ Eco-cup capsule and pyrolysed at $500{ }^{\circ} \mathrm{C}$. Compound identification was performed using AMDIS software integrated with NIST-Wiley database.

\section{Results and discussion}

The main deterioration features noticed in the three mural panels by visible and raking light were flaking lack of cohesion, erosion, and lacunae of paint layers. Particularly affected by severe flacking is a light greenish/greenish blue paint layer identified in the Angel's garment of P2 and in the other two panels in the background and in some decorative motifs [Figure1 to Figure 3].

Salt veils, salt concretions and salt efflorescence are clearly seen with the naked eye in P3 and P6 [Figure 2 and Figure 3]. The decay that the salts have induced over the past twenty years in P3 is shown in Figure 2. From detailed observation of the three sets of photographs from the late 1990s, 2013 and 2020 it is possible to conclude that this phenomenon is still ongoing. The occurrence of salts could have been trigger by water infiltration and condensation due to old and damaged installations and leaking pipes (Hanafi et al. 2018; Young 2008). It must be noted that within the main hall, the mural panels span over two stories high, which positions the floor joint in the middle of the paintings as illustrated in Figure 4. The most deteriorated areas of the mural panels are aligned with this junction favoring the occurrence of thermal bridges (Jedidi \& Benjeddou 2018; Zedan et al. 2016). A thermal bridge can be explained as the movement of heat across an object that is more conductive than the surrounding materials leading to heat loss. Thermal bridges in buildings, besides having an impact on thermal resistance, can cause water condensation within the architectural elements. This may be one of the reasons for the current state of conservation of the paint layers in panels P3 and P6.

In terms of deterioration, P6 presents the most complex case due to the extent and degree of the paint layers affected [Figure 1]. The main decay phenomena in this panel follows the pattern of the two previous ones: salts induced stress and subsequent flacking, lack of cohesion, erosion and lacunae of paint layers as shown in Figure 3 in Vis e Vis-Rak. 

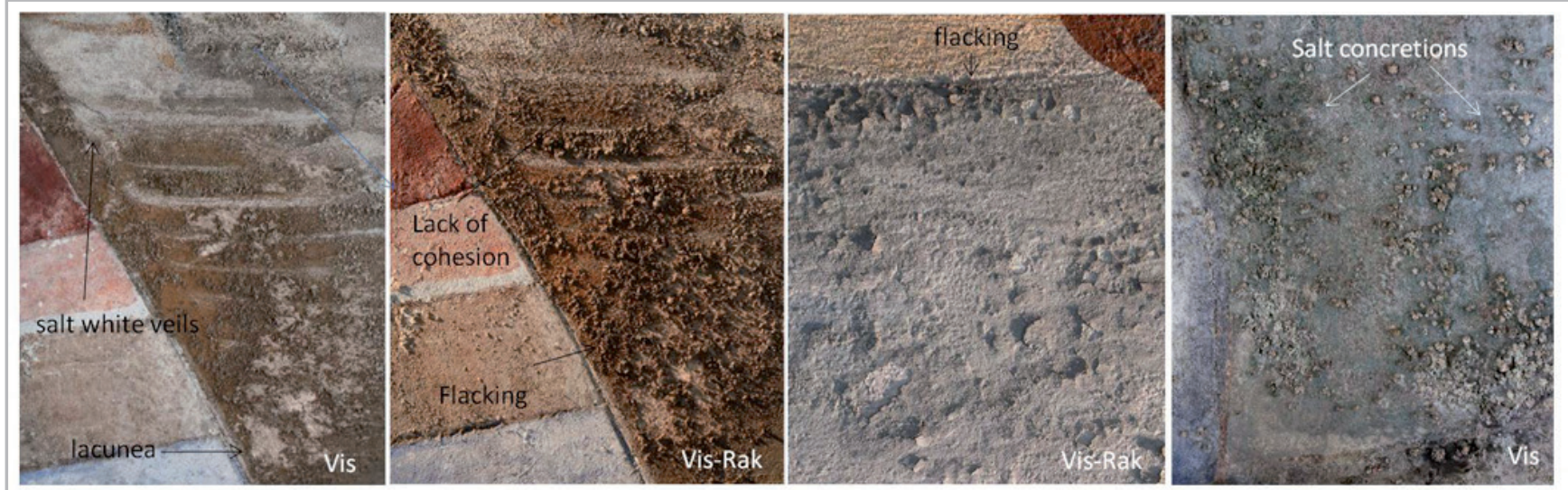

Figure 3.-Details in Vis and Vis-Rak of deterioration features in P6: flaking, lack of cohesion, lacunae, salt veils, concretions, and efflorescence.

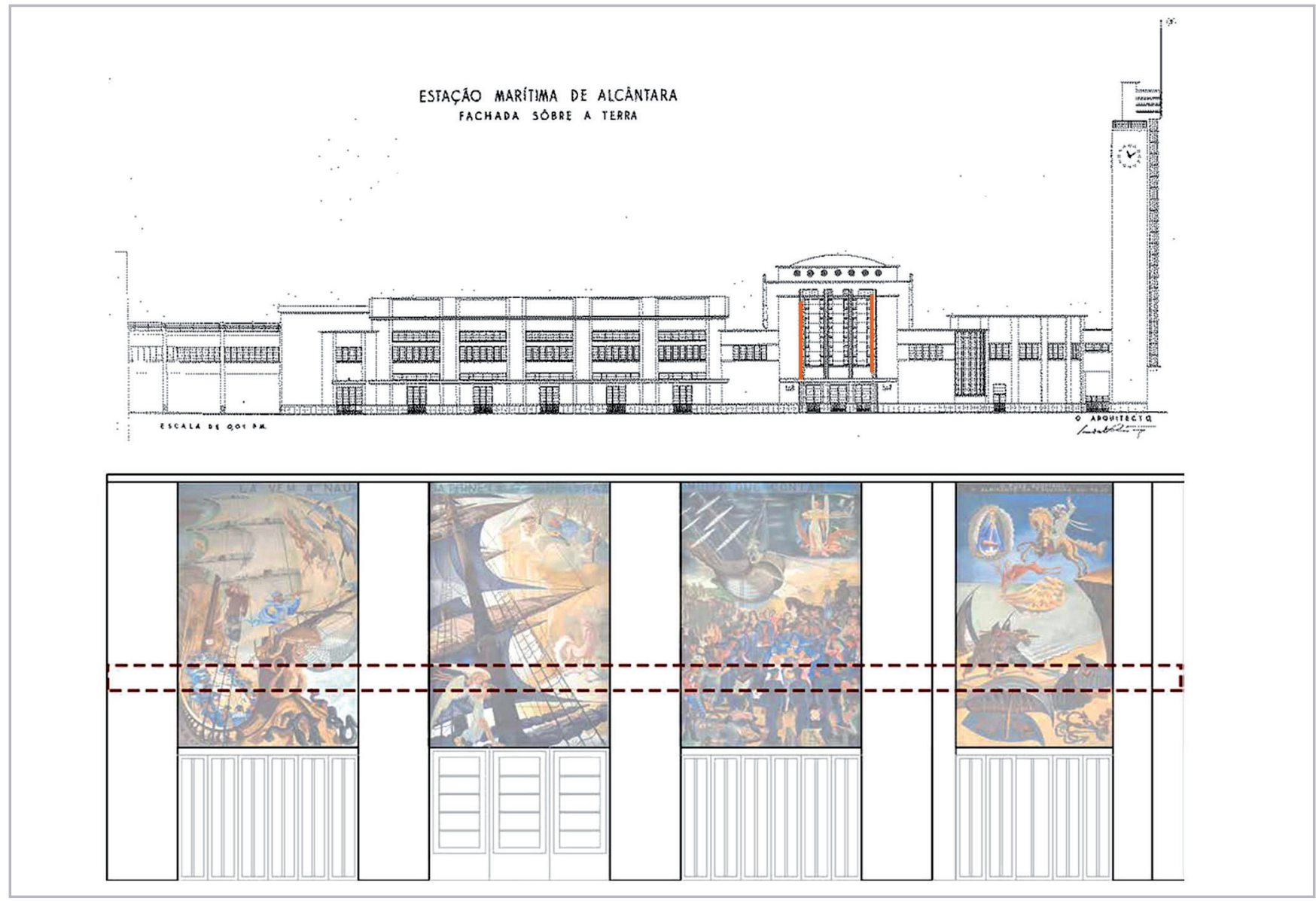

Figure 4.- On top, cross section of Alcântara station with marked positions of the murals. Source of the section (Monteiro 2012); on the bottom, scheme of the west wall with the display of the murals and indicated position of thermal bridge that corresponds with construction joint between two floors. Drawing by Mila Cvetković 2020.

\section{- Identification and characterization of salts}

Five powdered samples of salt efflorescence collected from P3 and P6 were analyzed by $\mu-X R D$, for mineralogical phase identification [Table 1, Figure 5]. The results obtained revealed that sulphates were the main phases found in all five samples: thenadrite $\left(\mathrm{Na}_{2} \mathrm{SO}_{4}\right)$, gypsum $\left(\mathrm{CaSO}_{4} \cdot 2 \mathrm{H}_{2} \mathrm{O}\right)$, syngenite $\left(\mathrm{K}_{2} \mathrm{Ca}\left(\mathrm{SO}_{4}\right)_{2} \cdot \mathrm{H}_{2} \mathrm{O}\right)$, aphthitalite $\left(\mathrm{K}_{3} \mathrm{Na}\left(\mathrm{SO}_{4}\right)_{2}\right)$ and anhydrite $\left(\mathrm{CaSO}_{4}\right)$ [Table1]. Calcite $\left(\mathrm{CaCO}_{3}\right)$ and barite $\left(\mathrm{BaSO}_{4}\right)$ were also found in most samples [Table1]. Gypsum was also identified in the eight deteriorated paint layers analyzed by $\mu$-FT-IR showing that this salt is widespread in the paint surfaces [Table 2].

Alkaline and alkaline earth sulfates are among the most common degradation agents in wall paintings (Salvadori et 


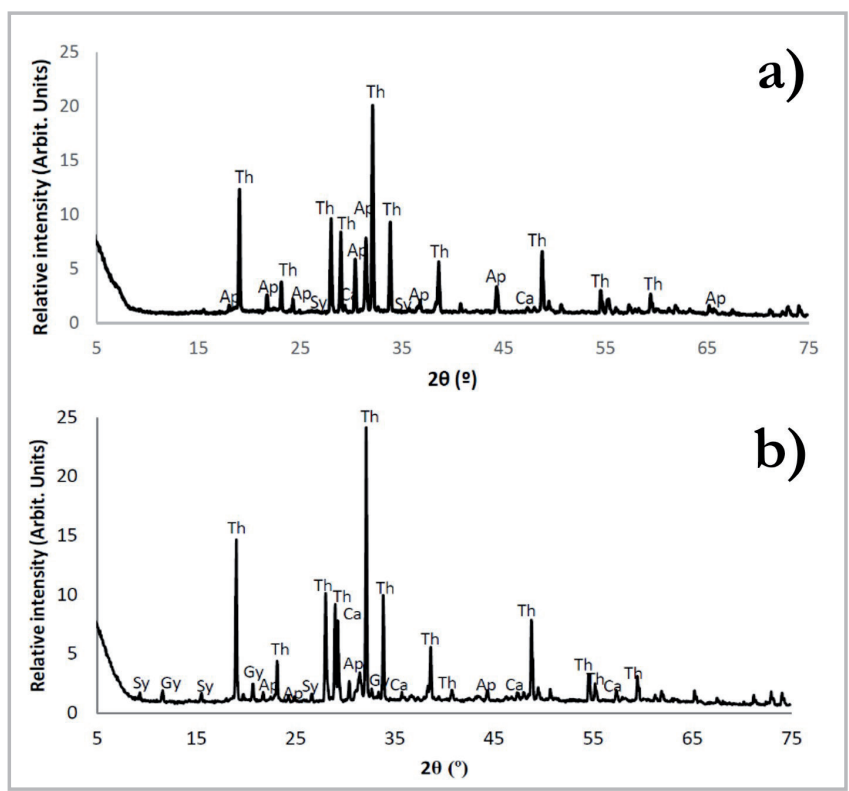

Figure 5.- XRD diffractograms of samples P3B_5 a) and P3B_6 b) showing identified mineralogical phases (Ca - Calcite, Th Thenardite, Sy - Syngenite, Ap - Aphthitalite, Gy - Gypsum).

al. 2003). Their formation in generally associated to the dry and wet acid deposition of $\mathrm{SO}_{\mathrm{x}}$ and the infiltration of water (Madariaga et al. 2014). In fact, the presence of water in buildings, even at a micrometric level, causes the leaching and migration of dissolved ions which are essential for the formation of efflorescence crystals (Madariaga et al. 2014). The composition of the building materials used is also an important factor in the type of salt efflorescence formed.

The formation of thenardite and aphthitalite, for example, can be associated to underground water and air pollution (El-Gohary 2011), or connected to the use of building materials such as cement which have significant amounts of alkalis in their composition (Pavía 2008). Moreover, previous researches have shown that syngenite can develop from Portland cement (Charola \& Bläuer 2015). In fact, in general, the period between 19th and 20 th century can be perceived as a transitional period between the use of lime-based binders and the general use of the modern Portland cement. This is also valid for Portugal (Figueiredo et al. 2019). As such, although there are no records of the use of Portland cement during the construction of the Maritime Stations, this possibility cannot be excluded.

Sodium sulphates, in general, can form efflorescence and sub-efflorescence causing, over time, the flaking of paint layers (El-Gohary 2011, 2008). Aphthitalite, with its complex crystallization behavior, can also be extremely damaging to building materials (Pavía 2008; Marszałek et al. 2020).

Gypsum is considered the most common salt efflorescence found in carbonated wall paintings (Salvadori et al. 2003). This calcium sulfate can also be found in construction materials such as cement (Azimi \& Papanagelakis 2011). The transformation of gypsum to anhydrite generally occurs at elevated temperatures (Azimi \& Papanagelakis 2011). However, the presence of sulfuric acid, as well as $\mathrm{NaCl}$, promotes and accelerates this transformation even at lower temperatures (Azimi \& Papanagelakis 2011). In this case, environmental factors can explain the presence of both sulfuric acid and sodium chloride, given that the first is the main constituent of acid rain, and the second is the primary component of sea spray.

Calcite detected in the salt efflorescence collected is most likely the result of minor amount of Ca-based paint layers and their underlying support being accidentally sampled. This is consistent with the lack of paint layer cohesion previously mentioned. On the other hand, the presence of barium sulphate, identified in the samples P3B_5 and P6A_15, can likely be associated to the pigments themselves, as this compound was frequently added as a filler by pigment manufacturers (Lähteenmäki 2009; Driel et al. 2016).

\section{- Characterisation of painting materials}

\section{- Pigment identification}

Table 2 reports the summary results of h-EDXRF obtained in eleven deteriorated paint layers and SEM-EDS and $\mu$-FTIR analysis of the corresponding micro-samples.

The analytical setup reveals the presence of Fe-based pigments in samples P6A_17, P6A_20, and P6C_2. The high

\begin{tabular}{|c|c|c|c|c|c|c|c|}
\hline \multirow{2}{*}{ Samples } & \multicolumn{7}{|c|}{ Mineralogical phases identified } \\
\hline & Thenardite & Gypsum & Syngenite & Aphthitalite & Anhydrite & Calcite & Barite \\
\hline P3B_5 & $\diamond$ & $\diamond$ & 0 & $\diamond$ & & $\diamond$ & 0 \\
\hline P3B_6 & 0 & & $\diamond$ & $\diamond$ & & $\diamond$ & \\
\hline P6A_2 & 0 & $\diamond$ & $\diamond$ & & $\diamond$ & & \\
\hline P6A_15 & $\diamond$ & $\Delta$ & 0 & & & 0 & $\diamond$ \\
\hline P6A_18 & 0 & 0 & & & & 0 & \\
\hline
\end{tabular}

Table 1.- Main mineralogical phases identified by $\mu$-XRD analysis in five salt efflorescence samples collected from paint layers of $\mathrm{P} 3$ and $\mathrm{P} 6$. 
Fe content found and the variable input of terrigenous elements such as $\mathrm{Al}, \mathrm{K}$ and $\mathrm{Si}$ in h-EDXRF strongly suggest that Almada Negreiros used ochre pigments to build up the warm hues. Characteristic bands of aluminosilicates at 3696, 3668, 3652, 3619, 1114, 1036, 1011, 914, 798, 781 $\mathrm{cm}^{-1}$ - were also identified by $\mu$-FT-IR in sample P6C_2.

Ochres are natural earth colorants and have been used since pre-historic times as pigments. Their color, ranging from yellow to red, comes mainly from iron oxides and hydroxides such as hematite (a-Fe2O3) and goethite (FeO(OH) (Gil et al. 2007). Manganese oxides are usually associated to brown shades and justified the Mn content found in P6C_2 [Table 2].

Almada Negreiros used ochres alone and, occasionally, in a mixture with small amounts of yellow/orange and red Cd-based pigments as detected by h-EDXRF [Table 2] in samples P6A_20 and in P6C_2 by SEM-EDS point analysis [Table 2, Figure 7a]. Cadmium pigments, unlike ochres, are synthetic and started to be produced and commercialized in a wide scale in the mid-1840s. Cadmium yellow is essentially cadmium sulfide (CdS) but as Fedler \& Bayard (1986) states, over the years several chemical and physical modifications have been developed to produce shades ranging from very light lemon yellow to light orange. An enrichment in Se is expected from deep oranges to reds $[\mathrm{Cd}(\mathrm{S}, \mathrm{Se})]$. It must also be noted that different red, orange, or yellow hues can be obtained by partial substitution of $\mathrm{Cd}$ with $\mathrm{Zn}$, or S with Se, within the crystal lattice of Cd pigments (Fedler\&Bayard 1986).

It is known that Almada Negreiros applied both kinds of Cd-based pigments in another mural painting set in Lisbon (DN building), and they have also been found in power form in his studio.

These findings are rare because in the past the use of $\mathrm{Cd}$ pigments in mural paintings, especially with fresco technique, was controversial. The stability of the pigments relied on their chemical composition and manufacture process. According to Feller (1986), cadmium yellow light hues were not advised since they could contain cadmium oxalate or carbonate, or even free sulfur, which would trigger reactions in the alkaline medium leading to a fast fading of the color. Maybe this can be the reason why Almada Negreiros limited the use of these pigments in these murals, but further research is needed to reach firm conclusions. However, it is important to note that in the two $\mathrm{Cd}$-containing paint layers analyzed by OM there is no evidence of pigment discoloration [Figure 6a]

In turn, h-EDXRF and SEM-EDS analyses of samples P3B_2 and P6A_7 collected from blue paint layers revealed the presence of $\mathrm{Na}, \mathrm{Al}, \mathrm{Si}, \mathrm{S}$ and $\mathrm{Cl}$ indicating the use of ultramarine blue pigment, a complex sulfurcontaining sodium aluminum silicate of formula $(\mathrm{Na}, \mathrm{Ca})_{8}\left(\mathrm{AlSiO}_{4}\right) 6\left(\mathrm{SO}_{4}, \mathrm{~S}, \mathrm{Cl}\right)_{2} \quad$ (Plaster1996). The synthetic deep opaque blue particles can be seen by OM reflected
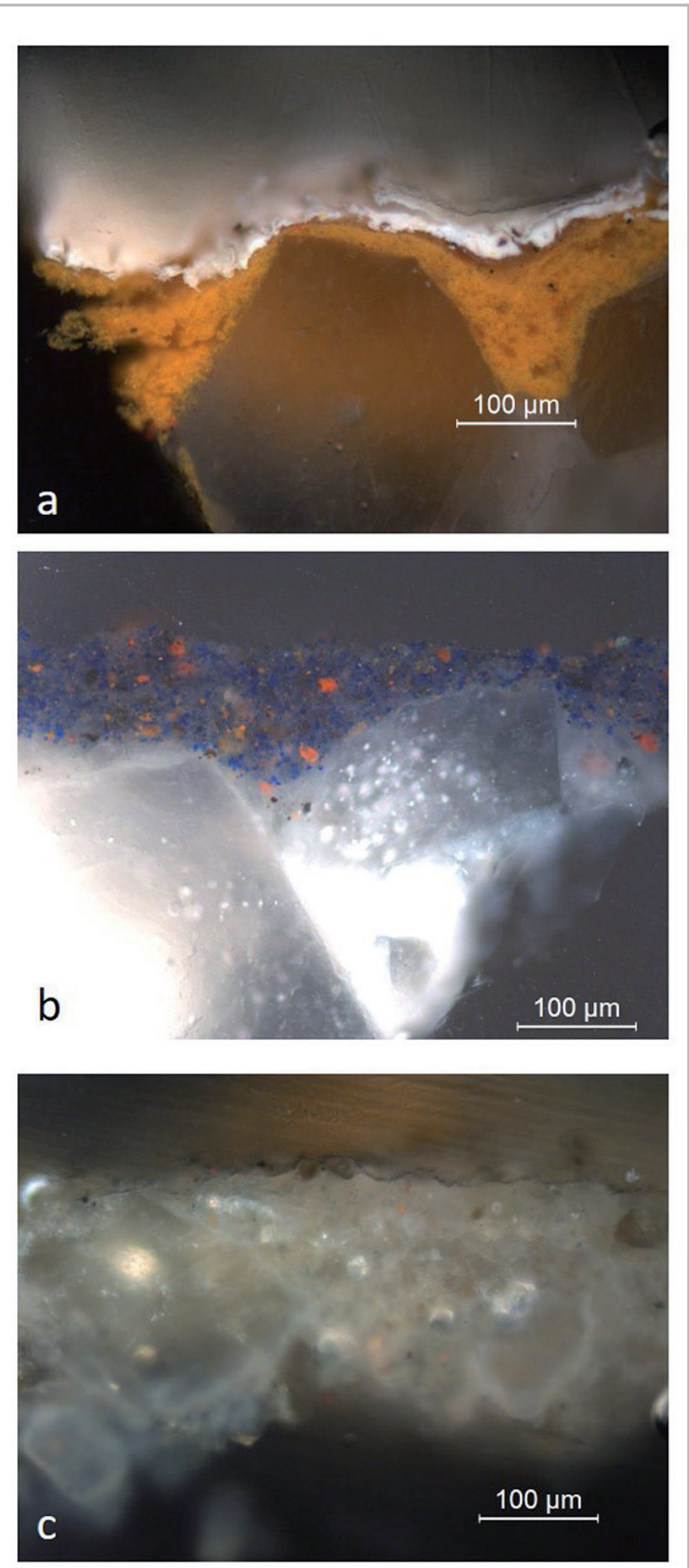

Figure 6.- OM-Vis of paint layers cross sections P6C_2(a), P3B_2(b) and P6C_5 at 200x magnification.

light as granules of uniform rounded shape and of size $\leq 4$ $\mu \mathrm{m}$ [Table 2, Figure 6b].

The identification of iron and phosphorous in the darker blue shade of sample P3B_2 suggests a combined use of ultramarine with ochres and bone black. Bone black has also been identified in an inner black paint layer in sample P6A_17 by $\mu$-FT-IR, due to the characteristic phosphate group band at $2013 \mathrm{~cm}^{-1}$. 
In what concerns the greens, h-EDXRF and SEM-EDS analyses of samples P2_4, P6A_3,P6A_23, and P6C_5 collected from the light greenish and greenish blue paint layers severely affected by flaking revealed the presence of $\mathrm{Fe}, \mathrm{Al}, \mathrm{K}, \mathrm{Mg}$, $\mathrm{Na}$ and $\mathrm{Si}$, which might imply the use of green earths [Table 2 , Figure6c]. Green earths are natural pigments containing as chromophores the clay minerals glauconite $(\mathrm{K}, \mathrm{Na})$ $\left(\mathrm{Fe}^{3+}, \mathrm{Al}, \mathrm{Mg}\right)_{2}(\mathrm{Si}, \mathrm{Al})_{4} \mathrm{O}_{10}(\mathrm{OH})_{2}$ and celadonite $\mathrm{K}\left(\mathrm{Mg}_{1} \mathrm{Fe}_{2}+\right)$ $\left(\mathrm{Fe}^{3+}, \mathrm{Al}\right)\left[\mathrm{Si}_{4} \mathrm{O}_{10}\right](\mathrm{OH})_{2}$ (Eastaugh et al. 2004).

Micro-samples P2_4 and P6A_3 also display high Ti content within the paint layers showing the use of $\mathrm{TiO}_{2}$ as a white pigment instead of calcium carbonate as it was expected in a fresco technique.

The identity of the chromophore remains unclear for samples P6A_14 and P6A_16 [Figure 7] collected from the bright and darker greens paint layers of the fishing boat in P6 [Figure 1]. Elemental analysis revealed an enrichment in $\mathrm{Fe}, \mathrm{Al}, \mathrm{K}, \mathrm{Cu}, \mathrm{As}, \mathrm{Sr}, \mathrm{Mg}, \mathrm{Si}, \mathrm{Ca}, \mathrm{Na}$, and $\mathrm{Cl}$, which could indicate different kinds of pigments combined with salts. Micro-FT-IR on P6A_14 and P6A_16 suggests the presence of emerald green pigment, a copper(II) acetoarsenite of formula $\mathrm{Cu}\left(\mathrm{CH}_{3} \mathrm{COO}_{2}\right) \cdot 3 \mathrm{Cu}\left(\mathrm{AsO}_{2}\right)_{2}$ based on the characteristic bands at 1556 and $1455 \mathrm{~cm}^{-1}$ (Cortea et al. 2020; Fiedler\&Bayeard 1997), but this assignment is still uncertain due to the absence of As in h-EDXRF [Table 2]. On the other hand, the Raman spectra of both green micro-samples reveal the following bands at 154, 196, 221, $314,353,381,449,472,497,537,618,636,670,754,883$, $1025,1077,1150,1225,1303,1353,1447,1471,1513,1552$ and $1590 \mathrm{~cm}^{-1}$, which could be tentatively assigned as the synthetic organic pigment PG 8 (Coccato et al. 2016).

\section{- Painting technique}

The painting technique was identified as fresco in sample cross-sections P3B_2, P6A_17, P6A_20, and P6C_2 collected from red, brownish, and blue paint layers. Painting at fresco implies the use of a fresh mortar to laid

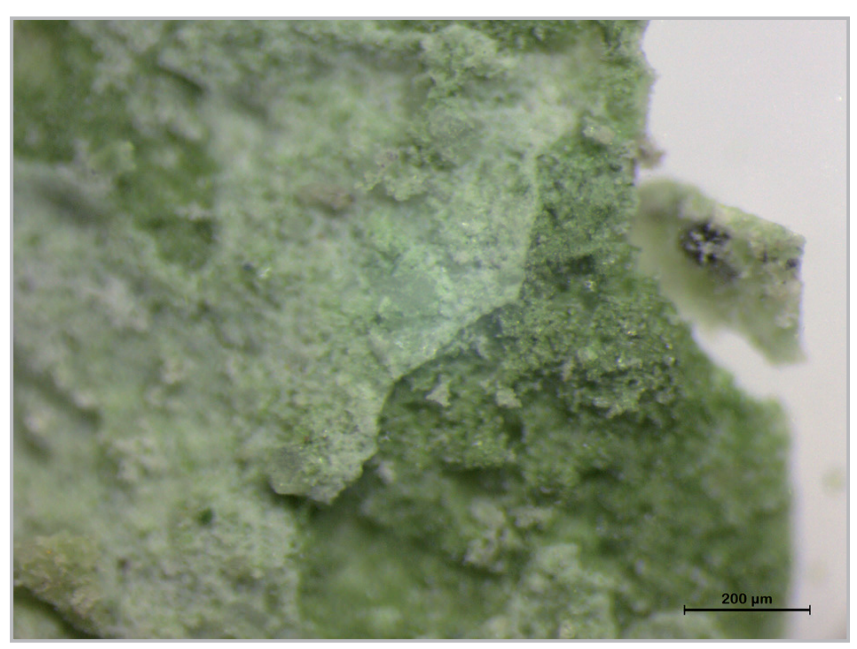

Figure 7.- OM-Vis of sample P6A_16 at 100x magnification. down the colors. Stratigraphically this technical feature can be ascertained by SEM-EDS in the interface mortar-paint layer by the absence versus the presence of a Ca-crust layer of carbonation. Its presence would suggest that the mortar surface was already dried when the painter started to paint. This was not the case of the paint layers analyzed. The absence of a Ca-rich crust is confirmed in the interface mortar-paint layer in SEM-EDS BSE images as seen in Fig.8. Furthermore, in most paint layers analyzed the pigment particles are embedded in a Ca matrix that can range up to $104 \mu \mathrm{m}$ thickness - a strong indication that the pigments were not mixed only with water (as in the case of buon fresco) but with a thicker solution of calcium hydroxide (e.g., lime milk) before being laid down on the fresh mortar (lime fresco technique).

Samples P2_4, P6A_3,P6A_23,P6C_5 P6A_14 and P6A_16 collected from the green paint layers present the most disruptive stratigraphy with loose material particles hindering the undisputed identification of the painting techniques used in their production.

Further examination was done using $\mu$-FT-IR and Py-GC/ MS on the samples that UVF indicated could have organic materials. Micro-FT-IR analyses of the samples P6A_23 and $\mathrm{P} 6 \mathrm{C} \_5$ from the greenish paint layers with a glossy appearance showed presence of vinyl polymer identified by characteristic bands at 2942, 2914 and $1376 \mathrm{~cm}^{-1}$.

Many acrylic and vinyl compounds were (and still are) used in the art and art conservation field as binding media, paint additives, coatings and consolidants (Schossler et al. 2013. In the case of the mural paintings in the Maritime station of Alcantâra, it is known that they were restored over the years. The unpublished intervention reports from Conservation Institute José de Figueiredo (IJF) and former conservatorsrestorers mention adhesion and consolidation treatments with Plextol (methyl methacrylate and ethy acrylate copolymer) and Calaton (soluble nylon) but it was not possible to confirm the presence of these products. So far only vinyl polymer was found as stated above. The origin of the vinyl polymer used apparently as an adhesive is still uncertain, but its presence was assigned in most of the greenish paint layers with severe flaking.

No biomarkers suggesting the use of organic binders were detected on eight samples analyzed by Py-GC/MS collected from similar green and blue paint layers in P2 and in P6. Some aromatic compounds with fused benzene rings such as indene or naphthalene were identified, but they may originate from the layer of soot covering the paint layer (Song \& Peng 2010). Oxalates identified by $\mu$-FT-IR analyses [Table 2], likely calcium oxalates given the Ca-rich matrix, may originate from lichen or algal activity (Peris-Vicente et al. 2009), but since no such activity was found on the analyzed samples other possibilities should be considered in further analyses as well, such as the reaction of calcium monoxide from the air with calcium carbonate from the painting surface (Peris-Vicente et al. 2009). 


\begin{tabular}{|c|c|c|c|c|c|}
\hline Location & Color & $\begin{array}{l}\text { h-EDXRF } \\
\text { (major elements for } \\
\text { pigments } \\
\text { identification in } \\
\text { bold) }\end{array}$ & $\begin{array}{l}\text { Micro- } \\
\text { sampling } \\
\text { Ref. }\end{array}$ & $\begin{array}{l}\text { SEM-EDS } \\
\text { (at.\%) }\end{array}$ & $\mu$-FT-IR \\
\hline $\begin{array}{l}\text { P2: angel's } \\
\text { dress }\end{array}$ & $\begin{array}{l}\text { Light } \\
\text { greenish } \\
\text { blue }\end{array}$ & $\begin{array}{l}\text { Al, Ba, Ca, Cl, Cu, } \\
\text { Fe, K, Mn, Ni, Pb, } \\
\text { S, Si, Sr, Zn }\end{array}$ & P2_4 & $\begin{array}{l}\mathrm{Na}(2.90), \mathrm{Mg}(9.52), \mathrm{Al}(9,43), \mathrm{Si} \\
(23,59), \mathrm{S}(14,60), \mathrm{Cl}(1,15), \mathrm{K}(1,85), \mathrm{Ca} \\
(27,14), \mathrm{Ti}(3.20), \mathrm{Fe}(6,63)\end{array}$ & $\begin{array}{l}\text { Calcite, Gypsum, } \\
\text { Barite, Oxalates }\end{array}$ \\
\hline $\begin{array}{l}\text { P3: sailor's } \\
\text { beret }\end{array}$ & Blue & $\begin{array}{l}\mathrm{Al}, \mathrm{Ca}, \mathrm{Cl}, \mathrm{Cu}, \mathrm{Fe} \\
\mathrm{K}, \mathrm{Mn}, \mathrm{Ni}, \mathrm{S}, \mathrm{Si}, \mathrm{Sr} \\
\text { Ti, Zn }\end{array}$ & P3B_2 & $\begin{array}{l}\text { [blue particles] } \mathrm{Na}(3,96), \mathrm{Al}(29,09), \mathrm{Si} \\
(25,82), \mathrm{S}(3,47), \mathrm{K}(2,71), \mathrm{Ca}(32,67), \mathrm{Fe} \\
(2,27)\end{array}$ & - \\
\hline $\begin{array}{l}\text { P6: } \\
\text { background }\end{array}$ & $\begin{array}{l}\text { Light } \\
\text { greenish }\end{array}$ & $\begin{array}{l}\mathrm{Al}, \mathrm{Ba}, \mathrm{Ca}, \mathrm{Cl}, \mathrm{Cu} \\
\mathrm{Fe}, \mathrm{K}, \mathrm{Mn}, \mathrm{Ni}, \mathrm{Pb} \\
\mathrm{Rb}, \mathrm{S}, \mathrm{Si}, \mathrm{Sr}, \mathrm{Ti}, \mathrm{Zn}\end{array}$ & P6A_3 & $\begin{array}{l}\mathrm{Na}(2,78), \mathrm{Mg}(1,87), \mathrm{Al}(1,99), \mathrm{Si}(2,49) \\
\mathrm{S}(1,15), \mathrm{Cl}(1,48), \mathrm{K}(0,93), \mathrm{Ca}(12,51) \\
\mathrm{Ti}(71,72), \mathrm{Cr}(0,79), \mathrm{Fe}(2,28)\end{array}$ & - \\
\hline $\begin{array}{l}\text { P6: shoulder } \\
\text { sleeve of the } \\
\text { first female } \\
\text { figure }\end{array}$ & Blue & $\begin{array}{l}\mathrm{Al}, \mathrm{Ba}, \mathrm{Ca}, \mathrm{Cl}, \mathrm{Cu}, \\
\mathrm{Fe}, \mathbf{K}, \mathrm{Mn}, \mathrm{Ni}, \mathrm{S}, \mathrm{Si} \\
\mathrm{Sr}, \mathrm{Ti}, \mathrm{Zn}\end{array}$ & P6A_7 & $\begin{array}{l}\text { [blue particles] } \mathrm{Na}(13,30), \mathrm{Mg}(0,68), \mathrm{Al} \\
(14,36), \mathrm{Si}(16,19), \mathrm{P}(0,80), \mathrm{S}(26,51), \mathrm{K} \\
(1,91), \mathrm{Ca}(26,25)\end{array}$ & - \\
\hline $\begin{array}{l}\text { P6: boat } \\
\text { behind the } \\
\text { second female } \\
\text { figure }\end{array}$ & Dark Green & $\begin{array}{l}\mathrm{Ba}, \mathrm{Ca}, \mathrm{Cl}, \mathrm{Cu}, \mathrm{Fe} \\
\mathrm{K}, \mathrm{Mn}, \mathrm{Ni}, \mathrm{S}, \mathrm{Si}, \mathrm{Sr} \\
\mathrm{Zn}\end{array}$ & P6A_14 & $\begin{array}{l}\mathrm{Na}(1,83), \mathrm{Al}(2,51), \mathrm{S}(36,49), \mathrm{Cl}(1,79), \\
\mathrm{K}(0,64), \mathrm{Ca}(17,35), \mathrm{Fe}(3,10), \mathrm{As} \\
(2,80), \mathrm{Sr}(2,79), \mathrm{Ba}(30,68)\end{array}$ & $\begin{array}{l}\text { Gypsum, Calcite, } \\
\text { Calcium Oxalate, } \\
\text { Barite } \\
\text { Emerald Green? }\end{array}$ \\
\hline $\begin{array}{l}\text { P6: boat } \\
\text { behind the } \\
\text { second female } \\
\text { figure }\end{array}$ & Green & $\begin{array}{l}\mathrm{Ba}, \mathrm{Ca}, \mathrm{Cl}, \mathrm{Cu}, \mathrm{Fe}, \\
\mathrm{K}, \mathrm{Mn}, \mathrm{Ni}, \mathrm{S}, \mathrm{Si}, \mathrm{Sr} \\
\mathrm{Zn}\end{array}$ & P6A_16 & - & $\begin{array}{l}\text { Barite, } \\
\text { Emerald Green? }\end{array}$ \\
\hline $\begin{array}{l}\text { P6: dress } \\
\text { sleeve of the } \\
\text { second female } \\
\text { figure }\end{array}$ & $\begin{array}{l}\text { Dark } \\
\text { brownish } \\
\text { red layer } \\
\text { over a black }\end{array}$ & $\begin{array}{l}\mathrm{Al}, \mathrm{Ca}, \mathrm{Cl}, \mathrm{Cu}, \mathrm{Fe} \\
\mathrm{K}, \mathrm{Mn}, \mathrm{Ni}, \mathrm{S}, \mathrm{Si}, \mathrm{Sr} \\
\mathrm{Ti}, \mathrm{Zn}\end{array}$ & P6A_17 & $\begin{array}{l}\text { [red particle] } \mathrm{Na}(5.97), \mathrm{Mg}(3.27), \mathrm{Al} \\
(2.97), \mathrm{Si}(1,49), \mathrm{P}(1,25), \mathrm{S}(2.36), \mathrm{Cl} \\
(1,14), \mathrm{Ca}(24,67), \mathrm{Fe}(56,90) \\
\text { [black particle] } \mathrm{Na}(5,57), \mathrm{Mg}(1,91), \mathrm{Ak} \\
(1,10), \mathrm{P}(17,80), \mathrm{S}(3,10), \mathrm{Cl}(0.89), \mathrm{K} \\
(1,5), \mathrm{Ca}(66,57), \mathrm{Fe}(1.56)\end{array}$ & $\begin{array}{l}\text { Gypsum, } \\
\text { calcite, } \\
\text { Silicates, } \\
\text { bone black }\end{array}$ \\
\hline $\begin{array}{l}\text { P6: arm of the } \\
\text { second female } \\
\text { figure }\end{array}$ & Flesh & $\begin{array}{l}\mathrm{Ba}, \mathrm{Ca}, \mathrm{Cd}, \mathrm{Cl}, \mathrm{Cu} \\
\mathrm{Fe}, \mathrm{Mn}, \mathrm{Ni}, \mathrm{Pb}, \mathrm{S} \\
\mathrm{Si}, \mathrm{Sr}, \mathrm{Ti}, \mathrm{Zn}\end{array}$ & P6A_20 & $\begin{array}{l}\text { [reddish particles]: } \mathrm{Na}(4,73), \mathrm{Mg}(2,87), \\
\mathrm{Al}(3,95), \mathrm{Si}(1,70), \mathrm{S}(9,42), \mathrm{Cl}(2,87), \\
\mathrm{Ca}(64,60), \mathrm{Fe}(9,86)\end{array}$ & $\begin{array}{l}\text { Gypsum, } \\
\text { Oxalates, } \\
\text { Silicates }\end{array}$ \\
\hline $\begin{array}{l}\text { P6: } \\
\text { background }\end{array}$ & $\begin{array}{l}\text { Light } \\
\text { greenish }\end{array}$ & $\begin{array}{l}\text { Al, Ba, } \mathrm{Ca}, \mathrm{Cl}, \mathrm{Cu} \\
\text { Fe, K, Mn, Ni, Pb, } \\
\text { Rb, S, Si, Sr, Ti, Zn }\end{array}$ & P6A_23 & $\begin{array}{l}\mathrm{Mg}(10,24), \mathrm{Al}(8,57), \mathrm{Si}(16,87), \mathrm{S} \\
(5,16), \mathrm{Cl}(1,16), \mathrm{K}(0,59), \mathrm{Ca}(4,95), \mathrm{Fe} \\
(50,15), \mathrm{Ba}(2,31)\end{array}$ & $\begin{array}{l}\text { Gypsum, Calcite, } \\
\text { Oxalates, Barite } \\
\text { Vynil Polymer }\end{array}$ \\
\hline $\begin{array}{l}\text { P6: rope of the } \\
\text { boat }\end{array}$ & $\begin{array}{l}\text { White layer } \\
\text { over an } \\
\text { orange } \\
\text { yellow }\end{array}$ & $\begin{array}{l}\mathrm{Al}, \mathrm{Ca}, \mathrm{Cl}, \mathrm{Cu}, \mathrm{Fe} \\
\mathrm{Mn}, \mathrm{Ni}, \mathrm{Pb}, \mathrm{S}, \mathrm{Si} \\
\mathrm{Sr}, \mathrm{Ti}, \mathrm{Zn}\end{array}$ & P6C_2 & $\begin{array}{l}\text { [top white layer] } \mathrm{Na}(3,14), \mathrm{Mg}(2,18, \\
\mathrm{Al}(3.19), \mathrm{Si}(3,07), \mathrm{P}(0,15), \mathrm{S}(2.46), \mathrm{Cl} \\
(0.94), \mathrm{Ca}(7,95), \mathrm{Ti}(71,72), \mathrm{Fe}(2,59), \\
\mathrm{Cd}(2,00) \\
\text { [ inner layer-yellow] } \mathrm{Na}(3,14), \mathrm{Mg} \\
(2,18), \mathrm{Al}(3,19), \mathrm{Si}(3,07), \mathrm{P}(0,75), \mathrm{S} \\
(2,46), \mathrm{Cl}(0,94), \mathrm{Ca}(7,95), \mathrm{Ti}(71,72), \mathrm{Fe} \\
(2,59), \mathrm{Cd}(2,00) \\
\text { [inner layer-orange particle] } \mathrm{Na}(3,65), \\
\mathrm{Mg}(3,27), \mathrm{Al}(15,47), \mathrm{Si}(27,52), \mathrm{P} \\
(1,68), \mathrm{S}(4,34), \mathrm{Cl}(1,62), \mathrm{Ca}(16,83), \mathrm{Fe} \\
(20,93), \mathrm{Cd}(2,62)\end{array}$ & $\begin{array}{l}\text { Aluminosilicates, } \\
\text { Gypsum, } \\
\text { Calcite, } \\
\text { Oxalates }\end{array}$ \\
\hline $\begin{array}{l}\text { P6: water } \\
\text { background } \\
\text { near the rope } \\
\text { (Fig.3d) }\end{array}$ & $\begin{array}{l}\text { Light } \\
\text { greenish } \\
\text { blue }\end{array}$ & $\begin{array}{l}\mathrm{Ba}, \mathrm{Ca}, \mathrm{Cl}, \mathrm{Cu}, \mathrm{Fe}, \\
\mathrm{K}, \mathrm{Mn}, \mathrm{Ni}, \mathrm{Pb}, \mathrm{S} \\
\mathrm{Si}, \mathrm{Sr}, \mathrm{Zn}\end{array}$ & P6C_5 & $\begin{array}{l}\text { Brownish green particle] } \mathrm{Na}(1,66), \mathrm{Mg} \\
(22,09), \mathrm{Al}(3.49), \mathrm{Si}(43,98), \mathrm{S}(1,48), \mathrm{Ca} \\
(15,63), \mathrm{Fe}(11,67)\end{array}$ & $\begin{array}{l}\text { Gypsum, Calcite, } \\
\text { Oxalates, } \\
\text { Vynil Polymer }\end{array}$ \\
\hline
\end{tabular}

Table 2.- Summary of h-EDXRF, SEM-EDS, and $\mu$-FT-IR of eleven paint layers analyzed. 

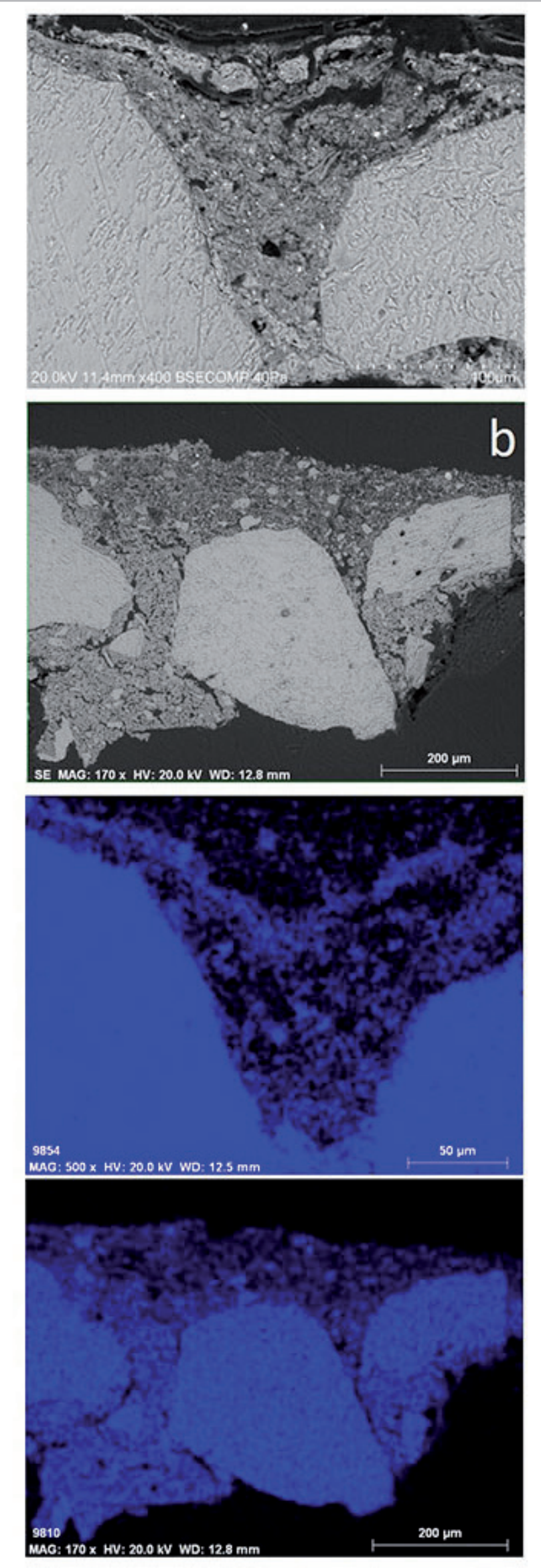

Figure 8.- SEM BSE images paint layers cross sections P6C_2(a), P3B_2(b) and corresponding EDS Ca elemental map distribution (in blue).

\section{Conclusions}

This paper reports for the first time a diagnostic research on deteriorated paint layers of Almada Negreiros' mural painting art in the city of Lisbon by in loco non-invasive and laboratory microanalytical techniques. The goal was to answer to the concerns of conservators-restorers stated in the three research questions regarding the state of conservation and decay mechanisms. The work carried out highlights the main deteriorations features noticed in the three murals made by the artist in 1945 .

All the paintings analyzed are affected by lack of cohesion, flaking, erosion and lacunae. The light greenish and greenish blue paint layers are particularly affected. First results of in situ and archival survey indicate salts as the main decay phenomenon which is still ongoing. Analysis of salt efflorescence samples and of samples of the affected paint layers revealed the presence of alkali and alkali eaeth sulphates as the main agents responsible for the current state of conservation of the paintings. The origin of the salts might be related to structural architectural deficiencies, the building materials used (e.g. Portland cement), and to the environmental conditions caused by the proximity to the sea and by the pollution of the city.

The results also show that Almada Negreiros used new synthetic painting materials that go beyond the traditional palette of a fresco painting technique employing these pigments alone or in mixtures (e.g., titanium white, $\mathrm{Cd}$ based pigments). The characterization of the green paint layers was not straightforward, and more research is needed to confirm the hypothesis raised at this point of research for the pigments' identification. Finally, in what concerns the painting technique used by Almada Negreiros, so far only, the fresco technique was identified in the paint layers analyzed but doubts remain in the most disrupted light greenish and greenish blue paint layers affected by flaking. Regardless of the remaining doubts, the analytical campaign enabled a comprehensive picture of the main deterioration features affecting the paint layers and the identification of the materials involved, both original and from previous interventions (e.g. the vinyl polymer). These data are crucial to build a structural review and to project future cleaning and consolidation measures of these paintings. Furthermore, the results will set the baseline for future analytical campaigns in these painting sets and in other mural painting nucleus of Almada Negreiros in the city of Lisbon.

\section{Acknowledgments}

This research has been conducted within the Erasmus Mundus Joint Master Program in Archaeological Materials Science (edition 2018-2020). The authors also acknowledge APL for allowing the study and FCT funding (Contract Program Ref. DL57/2017/CP1338/CT0001, Individual Scientific Employment Contract nr. CEECIND/00791/2017 
and Project PTDC/ART-HIS/1370/2020). M. Cvetković would also like to thank the Education, Audiovisual and Culture Executive Agency (EACEA) for his scholarship to attend the Erasmus Mundus Joint Master in ARCHaeological MATerials Science.

\section{References}

AZIMI, G.; PAPANGELAKIS, V. G. (2011). “Mechanism and kinetics of gypsum-anhydrite transformation in aqueous electrolyte solutions". Hydrometallurgy, 108(1-2): 122-129. https://doi. org/10.1016/j.hydromet.2011.03.007

CHAROLA, A. E.; BLÄUER, C. (2015). “Salts in Masonry: An Overview of the Problem". Restoration of Buildings and Monuments, 119-135. https://doi.org/10.1515/rbm-2015-1005

COCCATO, A.; BERSANI, D.; COUDRAY, A.; SANYOVA, J.; MOENS, L.; VANDENABEELE, P. (2016). "Raman spectroscopy of green minerals and reaction products with an application in Cultural Heritage research". Journal of Raman Spectroscopy, 47: 14291443. https://doi.org/10.1002/jrs.4956

CORTEA, I. M. et al. (2020). "Uncovering hidden jewels: an investigation of the pictorial layers of an 18th-century Taskin harpsichord". Heritage Science, 8(55). https://doi.org/10.1186/ s40494-020-00401-3

DRIEL, B. A. V., VAN DEN BERG, K. J., GERRETZEN, J.; DIK, J. (2016). "The white of the 20th century: an explorative survey into Dutch modern art collections". Heritage Science, 6(16). https://doi. org/10.1186/s40494-018-0183-4

EL-GOHARY, M. (2008). "Air Pollution and Aspects of Stone Degradation Umayyed Liwân - Amman Citadel as a Case Study". Journal of Applied Science Research, 4(6): 669-682.

EL-GOHARY, M. (2011). "Chemical deterioration of Egyptian limestone affected by saline water". International Journal of Conservation Science, 2(1): 17-28.

EASTAUGH N.; WALSH V.; CHAPLIN T.; SIDDALL R. (2004). The pigment compendium: a dictionary of historical pigments. Elsevier Butterworth-Heinemann.

FIEDLER I.; BAYARD M. (1986). "Cadmium yellows, oranges, and reds" In Artists' Pigments: A Handbook of Their History and Characteristics, Volume 1. s.I.: (Editor) Feller, R. L., National Gallery of Art, Washington, Archetype Publications, London, 65-109.

FIGUEIREDO, C. et al. (2019). Natural cement in Portuguese heritage buildings. Lisbon: s.n.

FIEDLER I.; BAYARD M. (1997). “Emarald green and Scheele's Green” In Artists 'Pigments: A Handbook of Their History and Characteristics, Volume 3. s.l.: (Editor) Fitzhugh E. W., National Gallery of Art, Washington, Archetype Publications, London, 219-273.
FRANÇA, J.A. (2004). História da arte em Portugal. 6. O Modernismo: (século XX), s.l.: Presença.

FRANÇA, J.A. (2014). Glórias de almada. Lisbon: Lisbon: Instituto de História da Arte.

GIL, M. et al. (2007). “Yellow and red ochre pigments from southern Portugal: Elemental composition and characterization by WDXRF and XRD". Nuclear Instruments and Methods in Physics Research A, 580:728-731. https://doi.org/10.1016/j.nima.2007.05.131

HANAFI, M. H. et al. (2018). "An Introduction to Thermal Bridge Assessment and Mold Risk at Dampness Surface for Heritage Building". IOP International Conference on Materials Engineering and Science.

JEDIDI, M.; BENJEDDOU, O. (2018). "Effect of Thermal Bridges on the Heat Balance of Buildings". International Journal of Scientific Research in Civil Engineering, 2(5): 41-49.

LÄHTEENMÄKI, L. (2009). "Combinations of titanium dioxide and fillers in paints". Degree Program in Chemical Engineering.

LOBO, P. R. (2014). "Almada and the Maritime Stations: The portrait of Portugal that the dictatorship wanted to erase". Revista de História da Arte, 2: 342-352.

MADARIAGA, J. M.; MAGUREGUI, M.; DE VALLEJUELO, S. F. O.; KNUUTINEN, U.; CASTRO, K.; MARTINEZ-ARKARAZO, I.; GIAKOUMAKIA, A.; PITARCH, A. (2014). "In situ analysis with portable Raman and ED-XRF spectrometers for the diagnosis of the formation of efflorescence on walls and wall paintings of the Insula IX 3 (Pompeii, Italy)". Journal of Raman Spectroscopy, 45(1112): 1059-1067.https://doi.org/10.1002/jrs.4611

MARSZAŁEK, M.; DUDEK, K.; GAWEŁ, A. (2020). "Cement Render and Mortar and Their Damages Due to Salt Crystallization in the Holy Trinity Church, Dominicans Monastery in Cracow, Poland". Minerals, 10(7), 641. https://doi.org/10.3390/min10070641

MONTEIRO, J. P. (2012). Dissertação para Obtenção do grau Doutor en Design: Para o projecto global - nove décadas de obra: Arte, Design e Técnica na Arquitetura do atelier Pardal Monteiro. s.l.: Lisboa: Universidade Técnica de Lisboa, Faculdade de Arquitetura.

PAVÍA, S. (2008). "Sulfation of a decrepit Portland cement mortar and its adjacent masonry". In SWBSS- Salt Weathering on Buildings and Stone Sculptures. Copenhagen: Technical University of Denmark.

PERIS-VICENTE, J. et al. (2009). "Characterization of Commercial Synthetic Resins by Pyrolysis-Gas Chromatography/Mass Spectrometry: Application to Modern Art and Conservation". Analytical Chemistry, 81:3180-3187. https://doi.org/10.1021/ac900149p

PLASTER J, A. (1993). "Ultramarine Blue natural and artificial". In Artists' Pigments: A Handbook of Their History and Characteristics, Volume 2. s.l.: (Editor) Ashok Roy, National Gallery of Art, Washington, Archetype Publications, London, 37-67. 
SALVADORI, B.; ERRICO, V.; MAURO, M.; MELNIK, E.; DEI, L. (2003). "Evaluation of Gypsum and Calcium Oxalates in Deteriorated Mural Paintings by Quantitative FTIR Spectroscopy", Spectroscopy Letters, 36(5-6): 501-513, https://doi.org/10.1081/SL-120026615

SCHOSSLER, P.; FORTES, I.; CURA D'ARS DE FIGUEIREDO JÚNIOR; ANTÔNIO CRUZ SOUZA, L. (2013). "Acrylic and Vinyl Resins Identified by Pyrolysis-Gas Chromatography/Mass Spectrometry: A Study of Cases in Modern Art Conservation". Analytical Letters, 46(12): 1869-1884. https://doi.org/10.1080/00032719.2013.7779 $\underline{25}$

SONG, J.; PENG, P. (2010). "Characterisation of black carbon materials by pyrolysis-gas chromatography-mass spectrometry". Journal of Analytical and Applied Pyrolysis, 87: 129-137. https:// doi.org/10.1016/j.jaap.2009.11.003

YOUNG, D. (2008). "Salt attack and rising damp: A guide to salt damp in historic and older buildings". Heritage Council of NSW, Heritage Vistoria, South Australian Department for Environment and Heritage, Adelaide City Council.

ZEDAN, M. F.; AL-SANEA, S.; AL-MUJAHID, A.; AL-SUHAIBANI, Z. (2016). "Effect of Thermal Bridges in Insulated Walls on AirConditioning Loads Using Whole Building Energy Analysis". Sustainability, 8(6): 560. https://doi.org/10.3390/su8060560

\section{Author/s}

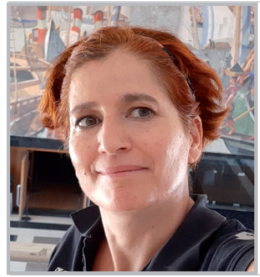

Milene Gil
milenegil@uevora.pt
HERCULES Laboratory (University of Évora),
Portugal
https://orcid.org/0000-0002-5779-2630

Milene Gil is a conservator restorer of Mural paintings and a researcher of Conservation Science at HERCULES Laboratory (Evora University). She has completed her $\mathrm{PhD}$ in 2010 in Conservation and restoration of Cultural Heritage, field of expertise Theory, History and Techniques of Artistic Production. She is the PI of the project Unveiling the Mural Art of Almada Negreiros PTDC/ART-HIS/1370/2020.

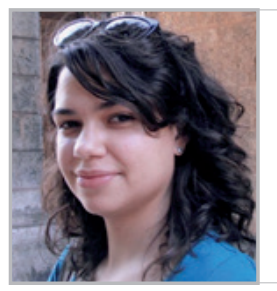

Mafalda Costa
mcosta@uevora.pt
HERCULES Laboratory (University of Évora),
Portugal
https://orcid.org/0000-0001-8764-2310

Mafalda Costa is a geologist and a researcher in the HERCULES Laboratory (University of Évora). Since 2014, she has been working in the field of archaeometry, using analytical techniques to determine the chemical and mineralogical composition of a wide range of inorganic materials recovered from Cultural Heritage contexts.
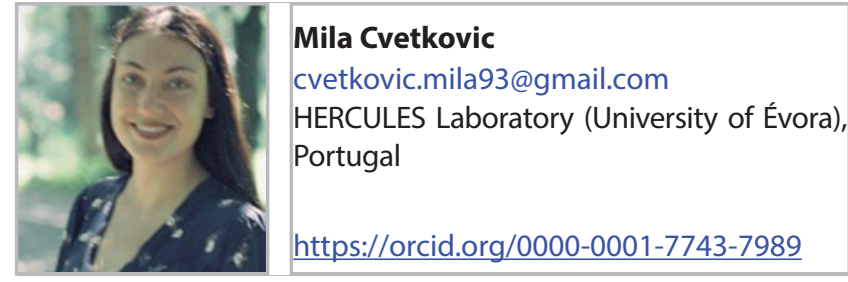

Mila Cvetković finished architecture studies at the Faculty of Civil Engineering and Architecture in Niš, Serbia. She holds master degrees in architecture (class 2016/17, GAF, University of Niš) and in archaeological materials science (ArchMat, class 2018/20). She is a PhD candidate and a former teaching associate at the Faculty of Civil Engineering and Architecture.
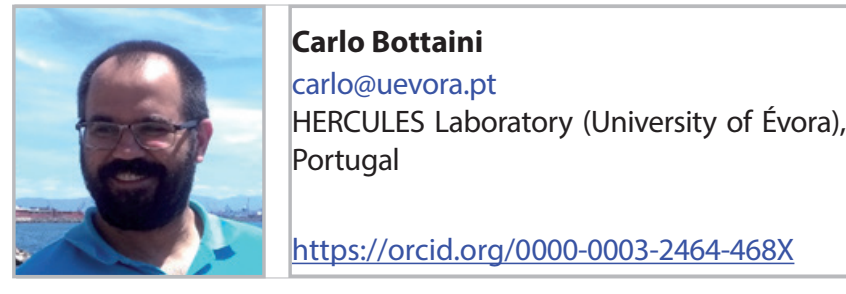

Carlo Bottaini is an archaeologist. He completed his $\mathrm{PhD}$ at the University of Coimbra (Portugal) in 2013. He is currently researcher at the HERCULES Lab, and he is a member of the CityUMacau Chair in Sustainable Heritage (University of Évora). Much of his research is concerned with exploring the dynamics of societal change in later prehistory of Western Europe and Mediterranean through the analysis of material culture and technologies.

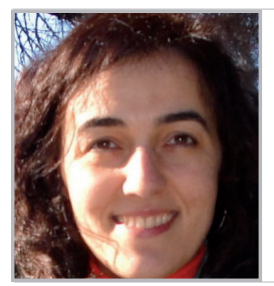
Ana Margarida Cardoso
anamacardoso@yahoo.com
HERCULES Laboratory (University of Évora) Portugal
https://orcid.org/0000-0002-4935-3398

Ana Margarida Cardoso has a master's degree in Materials Engineering. She held an internship at the Institute of Museums and Conservation in the Laboratory José de Figueiredo (LJF) under the Internship Program in Public Administration in 2006. Since then has collaborated on several projects funded by FCT in Portugal, at the LJF and HERCULES Laboratory, with special focus on materials characterization through vibrational spectroscopy and microscopic techniques. She works as a higher technician and she is a PhD student in chemistry at the University of Évora.

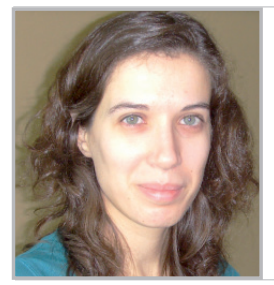
Ana Manhita
anaccm@uevora.pt HERCULES Laboratory (University of Évora), Portugal

\section{https://orcid.org/0000-0002-6350-9408}

Ana Manhita is a Chemist and Assistant Researcher at HERCULES Laboratory, University of Évora, Portugal. She completed her PhD in Chemistry in 2012, focused on the material study of historical 
textiles. She mainly develops her research in the field of analytical chemistry applied to the study of cultural heritage objects, with special emphasis on the application of advanced chromatographic techniques for the study of organic materials.

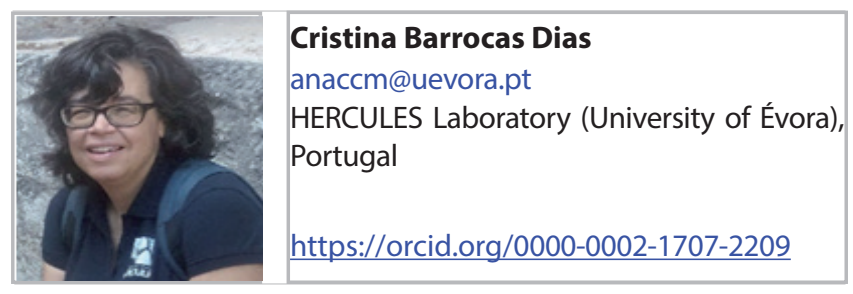

Cristina Barrocas Dias is an Associate Professor and Deputy-Director of the HERCULES Laboratory, University of Évora. Her research expertise is the analysis of organic compounds by hyphenated chromatographic methods (LC-MS and GC-MS). Recently she has expanded her interests into the analysis of stable isotopes applied to cultural heritage.

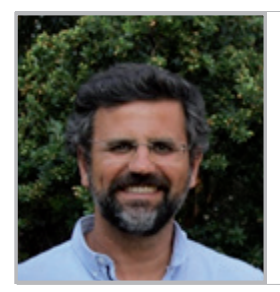

\section{António Candeias}

acandeias@uevora.pt

Director of the Institute for Research and Advanced Training of the University of Evora, Portugal

https://orcid.org/0000-0002-4912-5061

Antonio Candeias is a Chemist specialized in surface chemistry and heritage science. Professor at the University of Évora since 1992, he was director of the HERCULES Laboratory from its creation in January 2009 until February 2019. He is currently Vice-Rector for Research and Development and, Director of the Institute for Research and Advanced Training of the University of Evora, Director of the national infrastructure ERIHS.pt (Portuguese platform of the European Infrastructure in Heritage Sciences) and Chairperson of the CityUMacau Chair in "Sustainable Heritage".

Artículo enviado el 28/07/2021 Artículo aceptado el 08/10/2021

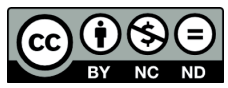

https://doi.org/10.37558/gec.v20i.1027 